\title{
MONAS SEBAGAI WAJAH DEWASA KOTA JAKARTA: ANALISIS MANAJEMEN REPUTASI DALAM PENGELOLAAN MONAS SEBAGAI IKON NEGARA
}

\author{
Bhernadetta Pravita Wahyuningtyas \\ Jurusan Marketing Communication, Fakultas Ekonomi dan Komunikasi \\ Universitas Bina Nusantara \\ Jln. K.H. Syahdan No. 9, Palmerah, Jakarta Barat 11480 \\ bhernadetta@gmail.com
}

\begin{abstract}
Article explains the management of Monumen Nasional (Monas)'s reputation, an Icon of Jakarta as well as a symbol of Indonesia. The study used post positivist paradigm, the nature of the study was descriptive and the selected approach was qualitative. Data compilation was done by in-depth interviews and observation, narrative analysis was applied. The aim of this study was to review the management of reputation of MONAS in its golden age. It can be concluded that Monas as an iconic monument or a symbol of Indonesia is improving continuously, therefore the people could be proud of it. The reputation management of MONAS is the results of coordination and socialization process within the institution, because the reputation achieved through cooperation of each department, and could not be achieved without communication.
\end{abstract}

Keywords: reputation management, institution reputation, state icon

\begin{abstract}
ABSTRAK
Artikel menjelaskan penelitian tentang upaya pihak pengelola Monas dalam menjadikan Monumen Nasional (Monas) sebagai ikon kota Jakarta khususnya, dan ikon negara, pada umumnya. Penelitian bertujuan mengulas manajemen reputasi yang dilakukan Monas sehubungan dengan usia emas-nya. Metode penelitian menggunakan paradigma post positivisme dengan pendekatan kulitatif yang bersifat deskriptif. Teknik pengumpulan data dilakukan dengan wawancara mendalam dan observasi. Metode analisis menggunakan analisis naratif. Disimpulkan, bahwa Monas sebagai sebuah ikon negara memang secara sadar terus berbenah diri, supaya reputasinya sebagai ikon negara yang patut dibanggakan layak disandang. Pengelolaan reputasi Monas merupakan wujud dari keseriusan dalam proses koordinasi dan sosialisasi dalam institusi, karena reputasi Monas dicapai melalui kerja sama semua pihak, bukan hasil kerja sendiri.
\end{abstract}

Kata kunci: manajemen reputasi, reputasi institusi, ikon negara 


\section{PENDAHULUAN}

Monumen Nasional atau yang lebih populer dengan sebutan Monas atau Tugu Monas, adalah sebuah monumen yang didirikan untuk mengenang perjuangan rakyat Indonesia dalam merebut kemerdekaan dari pemerintahan kolonial Hindia Belanda, selain sebagai monumen yang terus membangkitkan inspirasi dan semangat patriotisme generasi mendatang. Monumen peringatan setinggi 132 meter (433 kaki) ini mulai dibangun pada tanggal 17 Agustus 1961 atas perintah presiden Sukarno, kemudian diresmikan dan dibuka untuk umum pada 12 Juli 1975. Tugu ini dimahkotai oleh lidah api berlapis lembaran emas perlambang semangat perjuangan yang berkobar-kobar tanpa pernah padam.

Sering kita mendengar komentar yang dilontarkan oleh warga luar Jakarta yang berkata, "Belum ke Jakarta, jika belum ke Monas.” Komentar tersebut menggambarkan posisi Monas sebagai sebuah ikon dari kota Jakarta, ibukota Republik Indonesia. Sebagai ikon sebuah ibu kota negara; bahkan mengacu pada latar belakang sejarah, tujuan pembangunan Monas, dan nama Monas sendiri, monumen ini merupakan sebuah monumen yang menjadi ikon dari negara kesatuan Republik Indonesia yang besar. Pada hakikatnya Monas selayaknya membanggakan. Tetapi, apakah Monas memang patut dibanggakan?

Jumlah orang yang berkunjung ke Monas setiap tahun tidaklah signifikan dibandingkan dengan jumlah warga Jakarta yang berjumlah sekitar 12 juta jiwa. Pada tahun 2009, Monas dikunjungi oleh 1.242.470 orang. Tahun 2010 pengunjung Monas berjumlah 1.057.951 orang, atau turun sekitar 1,2 \%. Padahal, berdasarkan sensus tahun 2010 diketahui bahwa pertumbuhan penduduk melebihi proyeksi nasional yaitu sebesar 237,6 juta jiwa dengan laju pertumbuhan penduduk (LPP) 1,49\% per tahun. Jika di tahun 2010 jumlah penduduk 237,6 juta jiwa maka di tahun 2011 jumlah penduduk Indonesia 241 juta jiwa. (http://www.republika.co.id/berita/nasional/umum/11/07/05/lnua4p-prediksibkkbn-2011-penduduk-indonesia-241-juta-jiwa, diunduh pada hari selasa, 27 September 2011, pada pukul 03.57).

Rekapitulasi data terakhir per bulan September tahun 2011, jumlah pengunjung Monas adalah 998.038 orang (dari dokumentasi Monas). Dari penduduk Indonesia sebanyak 241 juta jiwa, kita beralih ke jumlah Penduduk Jakarta. Berdasarkan hasil sensus 2011, populasi penduduk Jakarta sudah mencapai 9,6 juta jiwa, ditambah warga luar yang beraktivitas di Jakarta pada siang hari sebanyak 2,5 juta. "Dengan begitu di siang hari, populasi penduduk di Jakarta sudah mencapai 12,1 juta jiwa. (http://metropolitan.inilah.com/read/detail/1771282/jumlah-penduduk-jakarta-dekati-ambang-batas, diunduh pada hari selasa, 27 september 2011, pada pukul 03.59)

Dengan jumlah penduduk sebanyak itu dan perbandingan banyaknya jumlah pengunjung. Monas tergolong dikunjungi oleh sangat sedikit jiwa. Dengan biaya yang cukup murah, dan akses melalui transportasi yang relatif mudah, Monas, sebagai icon sebauah negara cukup memprihatinkan. Banyak acara yang diadakan di sana. Banyak fasilitas yang terbuka dan mampu dimanfaatkan secara positif oleh banyak jiwa, namun kenyataannya tidak sesuai dengan ekspektasi sebelumnya. Sekedar memperbandingkan, Tokyo Sky Tree Tower pada tahun fiskal 2006, mengalami kenaikan jumlah pengunjung yaitu tiga juta jiwa, naik sebesar 2.5 juta dari tahun sebelumnya, karena mereka memiliki fasilitas observatory (http://www.asahi.com/english/TKY201107090265.html, diunduh pada hari jumat, tanggal 30 September 2011, pukul 01.37). Observatory yang dimiliki oleh Tokyo Sky Tree Tower serupa atau sejenis dengan diorama yang dimiliki oleh Monas. Lalu, mengapa Monas sebagai Ikon besar sebuah negara yang juga memiliki banyak kegiatan, aktivitas, acara, dan fasilitas edukasi serupa, kurang mampu membuat penduduk Indonesia, khususnya Jakarta jatuh cinta kepadanya? 
Sebagai sebuah lambang atau ikon dari ibu kota negara, Monas (Monumen Nasional) selayaknya atau secara ideal, sebaiknya menjadi sebuah institusi yang mampu mengelola dan secara bekesinambungan mempertahankan reputasi. Monas adalah ikon negara. Bukan sekedar ikon sebuah ibu kota.

Pelbagai fasilitas telah disediakan oleh pengelola Monas; dimulai dari sarana transportasi yang sengaja disiapkan untuk pengunjung, yaitu kereta mini, sehingga para pengunjung tidak perlu berlelahlelah berjalan kaki dari landasan parkir kendaraan bermotor mereka menuju ke pintu masuk Monas. Kereta mini tersebut mengangkut penumpang secara bebas biaya atau gratis. Kereta mini ini juga membawa wisatawan atau para pengunjung berkeliling Monas, menikmati keindahan dan keagungan Monas. Fasilitas rekreasi untuk keluarga seperti Taman Monas yang menghadirkan tontonan air mancur menari (apalagi bila dilihat malam hari) yang didukung oleh teknologi pencahayaan yang begitu memamdai; ditambah lapangan olah raga, seperti lapangan futsal dan lapangan basket yang basket yang boleh digunakan secara gratis; hingga kesempatan untuk bermain dengan kawanan rusa yang didatangkan dari Istana Bogor. Biaya yang harus dikeluarkan untuk mendapatkan tiket masuk ke Monas relatif terjangkau, Rp 2.500,00 untuk pengunjung dewasa dan Rp 1.000,00 untuk pengunjung anak-anak di bawah 12 tahun.

Monas, tugu bermahkota lidah api, yang kokoh mematung, dan tegak berdiri agung itu berusia 50 tahun kini. Emas sudah tahun-tahun yang genap ia lewati. Namun, Reputasi Monas sebagai sebuah ikon negara nampaknya dianggap sepi. Ikon sepenting ini kurang dipandang dan diresapi sebagai ikon besar negara Republik Indonesia. Padahal ikon sebesar ini dinaungi oleh institusi yang tidak sederhana. Layaknya institusi dan ikon-ikon lain yang serupa, Monas juga tentunya mengalami dan menghadapi berbagai problema. Selayaknya problema yang ada ditangani dan diselesaikan sebaikbaiknya, atanpa melupakan identitas dan karakter Monas sebagai sebuah ikon negara.

Berdasarkan permasalahan diatas maka muncul pertanyaan penelitian yaitu:

1. Bagaimana upaya pengelola Monas untuk melakukan manajemen reputasi dalam mengelola Monas sebagai ikon Negara.

2. Apa kendala-kendala yang dapat menganggu menajemen reputasi Monas?

\section{METODE}

Paradigma penelitian ini bersifat post positivism, yaitu Secara epistemologis, Denzin dan Guba (2001) mengatakan bahwa hubungan antara pengamat dengan objek yang diteliti tidak bisa dipisahkan. Aliran post-positivis ini meyakini bahwa subjek tidak mungkin dapat mencapai atau melihat kebenaran, apabila pengamat berdiri di belakang layar tanpa ikut terlibat dengan objek secara langsung. Menurut Guba (1990:20), prediksi dan kontrol tetap menjadi tujuan dari Postpositivisme. Postpositivisme berpendapat manusia tidak mungkin mendapatkan kebenaran dari realitas apabila peneliti membuat jarak dengan realitas atau tidak terlibat secara langsung dengan realitas. Hubungan antara peneliti dengan realitas harus bersifat interaktif, untuk itu perlu menggunakan prinsip trianggulasi yaitu penggunaan bermacam-macam metode, sumber data, dan lain-lain.

Postpositivisme menyatakan bahwa adalah suatu hal yang tidak mungkin untuk mencapai atau melihat kebenaran apabila pengamat berdiri di belakang layar tanpa ikut terlibat dengan objek secara langsung. Oleh karena itu, hubungan antara pengamat dengan objek harus bersifat interaktif, dengan catatan bahwa pengamat harus bersifat senetral mungkin, sehingga tingkat subjektivitas dapat dikurangi secara minimal (Salim, 2001:40). 
Pendekatan yang digunakan oleh penulis dalam penelitian ini adalah pendekatan kualitatif yang bersifat deskriptif. Metodologi kualitatif adalah prosedur penelitian yang menghasilkan data deskriptif berupa kata-kata tertulis atau lisan dari orang-orang dan perilaku yang dapat diamati (Bogdan, 1982). Penelitian kualitatif adalah tradisi tertentu dalam ilmu pengetahuan sosial yang secara fundamental bergantung pada pengamatan pada manusia dalam kawasannya sendiri dan berhubungan dengan orang-orang tersebut dalam bahasanya dan dalam peristilahannya (Kirk, 1986). Sedangkan menurut Sugiyono (2009:9) metode penelitian kualitatif adalah metode penelitian yang berlandaskan pada filsafat postpositivisme, digunakan untuk meneliti pada kondisi obyek yang alamiah, dimana peneliti adalah sebagai instrumen kunci, teknik pengumpulan data dilakukan secara triangulasi (gabungan), analisis data bersifat induktif, dan hasil penelitian kualitatif lebih menekankan pada makna dari pada generalisasi.

Penelitian kualitatif menyusun desain yang secara terus menerus disesuaikan dengan kenyataan lapangan. Jadi, tidak menggunakan desain yang telah disusun secara ketat dan kaku sehingga tidak dapat diubah lagi. Hal itu disebabkan oleh beberapa hal. Pertama, tidak dapat dibayangkan sebelumnya tentang kenyataan-kenyataan ganda di lapangan; kedua, tidak dapat diramalkan sebelumnya apa yang akan berubah karena hal itu akan terjadi dalam interaksi antara peneliti dengan kenyataan; ketiga, bermacam sistem nilai yang terkait hubungan dengan cara yang tidak dapat diramalkan.

Menurut Prof. Dr. H. Hadari Nawawi (1995:63), metode deskriptif diartikan sebagai prosedur pemecahan masalah yang diselediki dengan menggambarkan atau melukiskan keadaan subyek atau obyek penelitian (seseorang, lembaga, masyarakat, dan lain-lain). Penelitian deskriptif juga bermaksud membuat penyadaran secara sistematis, faktual, dan akurat mengenai fakta-fakta dan sifat-sifat populasi tertentu (Usman, 1998:4). Jadi penelitian deskriptif yang akan dilakukan akan berusaha mendeskripsikan atau menggambarkan tentang Manajemen Reputasi yang dilakukan oleh pihak Monas dalam rangka menjadikan Monas sebagai sebuah Ikon Negara.

Lokasi penelitian ini bertempat di Kantor Pengelola Monumen Nasional, Provinsi DKI Jakarta, Jl. Kebon Sirih No.22 Blok H Lt.IX No.53, Jakarta Pusat.

Dalam penelitian ini, metode pengumpulan data yang digunakan adalah:

Data Primer: Penelitian primer membutuhkan data atau informasi dari sumber pertama, biasanya disebut sebagai responden. Data atau informasi diperoleh melalui pertanyaan tertulis dengan menggunakan kuesioner atau lisan dengan menggunakan metode wawancara (Sarwono, 2006:16).

a. Wawancara mendalam (in-depth-interview), menurut Bungin (Hamidi, 2007:108), "wawancara mendalam adalah suatu proses memperoleh keterangan untuk tujuan penelitian dengan cara tanya jawab sambil bertatap muka antara pewawancara dengan informan atau orang yang diwawancarai, dengan atau tanpa menggunakan pedoman wawancara, dimana pewawancara dan informan terlibat dalam kehidupan sosial yang relatif lama." Metode wawancara yang digunakan dalam penelitian ini adalah wawancara langsung, dimana penulis melakukan komunikasi verbal dengan orang yang menjadi sumber data secara langsung, tanpa perantara, baik tentang diri dan segala sesuatu yang berhubungan dengan dirinya.

b. Observasi, merupakan metode pengumpulan data yang dilakukan peneliti untuk mengamati atau mencatat suatu peristiwa dengan penyaksian langsungnya dan biasanya peneliti dapat sebagai partisipan atau observer dalam menyaksikan atau mengamati suatu objek peristiwa yang sedang ditelitinya (Ruslan, 2008:221).

Data Sekunder: Penelitian sekunder menggunakan bahan yang bukan dari sumber pertama sebagai sarana untuk memperoleh data atau informasi untuk menjawab masalah yang diteliti (Sarwono, 2006:17). Selain menggunakan wawancara dan observasi, pada data sekunder dibantu dengan dokumentasi. Dokumentasi merupakan metode pengumpulan data dengan cara mengambil data yang 
berasal dari dokumen asli. Dokumen asli tersebut dapat berupa gambar, tabel, atau daftar periksa dan film dokumenter (Hamidi, 2007:88)

Sebuah penelitian kualitatif yang menggunakan wawancara mendalam, terkait erat dengan narasumber penelitian atau informan. Menurut Moleng (2005: 132), informan merupakan individu yang dimanfaatkan untuk memberikan informasi tentang situasi dan kondisi latar penelitian. Jadi, informan harus mempunyai banyak infornasi tentang situasi dan kondisi latar penelitian. Ia berkewajiban secara sukarela menjadi anggota tim dengan kebaikan dan kesukarelaan tentang nilainilai, sikap, bangunan, dan kebudayaan yang menjadi latar penelitian tersebut. Dalam penelitian ini, informan yang diambil oleh peneliti adalah informan yang memiliki jabatan cukup krusial dalam tata kelola dan manjemen reputasi Monas. Informan adalah individu yang bertanggungjawab penuh pada perencanaan hingga pengawasan pelaksanaannya di lapangan. Informan berjumlah dua orang; mereka adalah Kepala Unit Pengelola Monumen Nasional (IMR) dan Kepala Seksi Pelayanan dan Edukasi $(\mathrm{SN})$.

Kepala Unit Pengelola Monas merupakan informan utama dari wawancara, karena tugasnya adalah memimpin, mengkoordinasikan, dan mempertanggungjawabkan pelaksanaan tugas dan fungsi dari unit pengelola (dalam hal ini termasuk tata kelola dan manajemen reputasi monas sebagai sebuah institusi), kemudian informan kedua adalah Kepala Seksi Pelayanan dan Edukasi, sebagai informan pendukung yang berfungsi menguatkan datum-datum yang didapatkan dari informan utama.

Teknik Analisis data yang digunakan dalam penelitian kualitatif adalah analisis data secara induktif. Analisis induktif ini digunakan karena beberapa alasan. Pertama, proses induktif lebih dapat menemukan kenyataan-kenyataan ganda sebagai yang terdapat dalam data; kedua, analisis induktif lebih dapat membuat hubungan peneliti-responden menjadi eksplisit, dapat dikenal, dan akontabel; ketiga, analisis demikian dapat menguraikan latar secara penuh dan dapat membuat keputusankeputusan tentang dapat-tidaknya pengalihan kepada suatu latar lainnya; keempat, analisis induktif lebih dapat menemukan pengaruh bersama yang mempertajam hubungan-hubungan; kelima, analisis demikian dapat memperhitungkan nilai-nilai secara eksplisit sebagai bagian dari struktur analitik.

Analisa data adalah proses mengorganisasikan dan mengurutkan data ke dalam pola, kategori, dan satuan uraian dasar sehingga dapat ditemukan tema dan dapat dirumuskan hipotesis kerja seperti yang disarankan oleh data. Dalam penelitian ini, peneliti menggunakan metode analisis naratif. Inti dari metode ini adalah kemampuannya untuk memahami identitas dan pandangan dunia seseorang dengan mengacu pada cerita-cerita (narasi) yang ia dengarkan atau tuturkan di dalam aktivitasnya sehari-hari (baik dalam bentuk gosip, fakta, berita, analisis, dan sebagainya, karena semua itu dapat disebut sebagai cerita). Fokus penelitian dari metode ini adalah cerita-cerita yang didengarkan di dalam kehidupan manusia sehari-hari. Di dalam cerita atau narasi, kompleksitas kultural kehidupan masyarakat ditangkap dan dituturkan dalam bahasa. Dalam konteks ini, cerita bukan sekedar cerita, melainkan menjadi bagian dari penelitian untuk memahami manusia dan dunianya, kemudian secara tetap membandingan satu data dengan data lainnya atau kategori lainnya (Webster dan Metrova, 2007: 13).

Analisis data adalah proses mengatur urutan data, mengorganisasikannya ke dalam suatu pola, kategori dan satuan uraian dasar. Ia membedakannya dengan penafsiran, yaitu memberikan arti yang signifikan terhadap hasil analisis, menjelaskan pola uraian, dan mencari hubungan diantara dimensidimensi uraian. Bogdan dan Taylor (dalam Moleong, 2005: 280), mendefinisikan analisis data sebagai proses yang terinci dari usaha formal untuk menemukan tema dan merumuskan hipotesis kerja (ide) seperti yang disarankan oleh data sebagai usaha untuk memberikan bantuan pada tema dan hipotesis kerja itu. 
Proses analisis data dimulai dengan menelaah seluruh data yang tersedia dari berbagai sumber, yaitu wawancara, pengamatan yang dituliskan dalam catatan lapangan, dokumen pribadi, dokumen resmi, gambar, foto, dan sebagainya (Moleong, 2005:247).

Subyektivitas peneliti biasanya menjadi hal yang dominan dalam penelitian kualitatif. Alat penelitian yang diandalkan adalah observasi dan wawancara mendalam, yang mengandung banyak kelemahan ketika dilakukan apalagi tanpa kontrol. Sumber data kualitatif diasumsikan kurang credible dan akan mempengaruhi akurasi penelitian. Menurut Bryman (2008: 376) ada beberapa cara menentukan keabsahan data penelitian kualitatif, yaitu:

Credibility (Kredibilitas); mengacu pada apakah proses dan hasil penelitian dapat diterima atau dipercaya. Penerapan derajat kepercayaan pada darnya menggantikan konsep validitas internal dari non-kualitatif. Dalam menguji keabsahan data, peneliti menggunakan teknik observasi secara terus menerus, dan cermat, sehingga peneliti dapat melihat secara langsung dan dapat memaparkan fenomena sosial yang diteliti seperti apa adanya. Dalam penelitian ini peneliti melakukan verbatim dari wawancara dan coding, sehingga dapat menganalisis secara akurat.

Transferability (Transferabilitas); mengacu pada apakah hasil penelitian ini dapat diterapkan pada situasi yang tidak serupa atau lain. Konsep validitas itu menyatakan bahwa generalisasi suatu penemuan dapat berlaku atau diterapkan pada semua konteks dalam populasi yang sama atas dasar penemuan yang diperoleh pada sample yang secara representative mewakili populasi tersebut. Dalam penelitian ini kualitas transferabilitas menyajikan data deskriptif, misalnya melalui latar belakang informan, dan peran informan dalam institusinya.

Dependability (Ketergantungan); mengacu pada konsistensi peneliti dalam mengumpulkan data, membentuk dan menggunakan konsep-konsep ketika membuat interpretasi untuk menarik kesimpulan. Penarikan kesimpulan dalam penelitian ini dilakukan secara cermat dan konsisten berdasarkan observasi dan wawancara mendalam yang sudah dilakukan oleh peneliti.

Confirmability (Konfirmabilitas); mengacu pada apakah hasil penelitian dapat dibuktikan kebenarannya, dimana hasil penelitian sesuai dengan data yang dikumpulkan. Hal tersebut dilakukan dengan cara memperlihatkan hasil penelitian pada informan atau mengkonfirmasi ulang jawaban informan sehingga hasil penelitian lebih obyektif.

\section{PEMBAHASAN}

Monas berusia 50 tahun sekarang. Dalam usia emasnya, reputasi monas sebagai sebuah ikon negara, dimana masyarakat justru lebih mengenalnya sebagai ikon ibukota semata, dipertaruhkan. Mampukah Monas membuktikan diri sebagai sebuah ikon negara yang bereputasi? Mengacu pada teori yang tertera pada bagian sebelumnya, inilah cara Monas mengelola reputasinya sebagai ikon sebuah negara.

Fombrun dan Rindova (dalam Balmer dan Greyser, 2003: 224) mengidentifikasi reputasi institusi ke dalam lima dimensi; yaitu: (a) alur sejarah; (b) mengacu pada kepentingan stakeholder internal dan eksternal, (c) bertitik tolak dari kegiatan atau tindakan masa lalu dan prestasi yang diraih; (d) besar-kecilnya manfaat yang diperoleh oleh kelompok-kelompok stakeholder individual; (e) penempatan institusi, baik di sisi pesaing, maupun di sekitar lingkungan bisnisnya.

Reputasi, merupakan aspek krusial yang patut diperjuangkan, dikelola dan dipertahankan oleh setiap institusi, sehingga institusi tersebut tetap kokoh di mata publiknya. Menurut Balmer dan Greyser, (2003:224) Reputasi institusi adalah bagaimana sebuah institusi mengelola urusan yang berkenaan dengan smenjadi emua konstituen yang mereka miliki; hal tersebut terkonsentrasi pada 
identitas atau karakter institusi. Identitas membatasi tindakan yang dilakukan oleh institusi; bagaimana mereka membuat keputusan, memperlakukan karyawan, dan bereaksi terhadap krisis. Identitas menjadi tulang punggung sebuah reputasi; ia menjelaskan jenis hubungan yang dibangun antara institusi dengan publik mereka yang paling penting, yaitu: konstituen, karyawan, konsumen, investor dan masyarakat lokal.

Sebagai sebuah kata, sebuah kondisi, dan/ atau situasi, Reputasi sulit untuk didefinisikan; karena rumitnya mengartikan atau mendefinisikan sebuah reputasi, maka Balmer dan Greyser (2003: 225) membaginya ke dalam enam (6) sudut pandang. Pertama adalah sudut padang ekonomi. Dari sisi ekonomi, reputasi didefinisikan sebagai persepsi yang dimiliki oleh pihak luar terhadap sebuah perusahaan. Para pelanggan atau pengguna atau pemakai perusahaan hanya dapat "melihat" kulit luar sebuah perusahaan, sebaliknya seorang manager yang memang berada dalam perusahaan tersebut dapat melihat keaslian dan keseluruhan kondisi perusahaan. Kadang kala, sebuah perusahaan yang merasa reputasinya tidak menonjol atau kurang berkarakter dalam arti posistif, akan dengan sukarela membayar sesosok individu yang populer dan terkenal karena memiliki reputasi yang baik. Sehingga reputasi baik dari individu tersebut dapat ikut mempengaruhi kredibilitas perusahaan di mata publik.

Kedua adalah sudut pandang strategi (Balmer dan Greyser, 2003: 226). Dari sisi strategi, reputasi didefinisikan sebagai sebuah hal yang sulit untuk ditiru atau diduplikasi, karena reputasi justru berasal dari keunikan-keunikan internal yang dimiliki sebuah institusi. Namun, harus diingat dan diindahkan, bahwa institusi harus terus memperhatikan batasan-batasan atau pergerakan reputasinya mengacu pada mobilitas yang juga dimiliki dan dilakukan oleh pesaing atau pihak lain. Secakap apapun reputasi kita, tetap saja akan ada pihak yang dapat mengimitasi reputasi tersebut. Meski mengimitasi atau meniru sebuah reputasi bukanlah perkara mudah, tetapi tetap saja kemungkinan semacam itu selalu ada dan terbuka lebar. Ketiga, sudut pandang pemasaran (Balmer dan Greyser, 2003: 227). Dalam pemasaran, reputasi dilihat sebagai brand image sebuah institusi. Dalam konteks ini, reputasi adalah hasil dari proses mencerna informasi yang menghasilkan gambaran tersendiri dalam pikiran individu atau seseorang. Ekuitas sebuah "brand" tercipta dari integritas antara kesadaran akan sebuah identitas sebuah "brand" dan juga program pemasarannya.

Keempat, sudut pandang organisasi (Balmer dan Greyser, 2003: 228). Dalam sudut pandang organisasi, reputasi tumbuh dari pengalaman para pekerja yang ada didalamnya. Reputasi dilatar belakangi oleh budaya organisasi dan didukung kuat oleh identitas korporasi. Budaya institusi mempengaruhi persepsi dan motivasi manager, sedangkan identitas institusi akan mempengaruhi bagaimana manager akan bereaksi dan mengintepretasi kondisi dan situasi yang terjadi di lingkungan sekitarnya. Identitas dan budaya merupakan dua hal yang saling berkaitan. Identitas memberi gambaran tentang keutamaan (inti), kelanggengan, dan fitur-fitur khas dari sebuah institusi, yang menghasilkan intepretasi tertentu yang kemudian ditularkan dan dibagikan antar para manager, dimana intepretasi tersebut dipakai untuk menangani atau menghadapi lingkungan atau pihak luar institusi.

Kelima, sudut pandang sosiologi (Balmer dan Greyser, 2003: 229). Dalam sudut pandang sosiologi, reputasi dinilai sebagai indikator dari sebuah legitimasi. Reputasi merupakan penilaian yang relatif terhadap harapan dan norma dalam bidang kelembagaan. Banyak pihak yang terlibat dan saling terkait dalam proses membangun sebuah reputasi. Keenam, sudut pandang akunting (Balmer dan Greyser, 2003: 229). Dalam sudut pandang akunting, reputasi dilihat sebagai aset yang tidak terlihat namun dapat diukur. Menurut susut pandang akunting, pengukuran berdasarkan finansial dianggap lebih baik dalam menilai sebuah reputasi.

\section{Sudut Pandang Ekonomi}

Dari sisi ekonomi, reputasi didefinisikan sebagai persepsi yang dimiliki oleh pihak luar terhadap sebuah perusahaan (Myers dan Majluf; Ross; Stigler; dalam Balmer dan Greyser, 2003: 226). Para pelanggan atau pengguna atau pemakai perusahaan hanya dapat "melihat" kulit luar sebuah 
perusahaan, sebaliknya seorang manager yang memang berada dalam perusahaan tersebut dapat melihat keaslian dan keseluruhan kondisi perusahaan. Kadang kala, sebuah perusahaan yang merasa reputasinya tidak menonjol atau kurang berkarakter dalam arti posistif, akan dengan sukarela membayar sesosok individu yang populer dan terkenal karena memiliki reputasi yang baik. Sehingga reputasi baik dari individu tersebut dapat ikut mempengaruhi kredibilitas perusahaan di mata publik.

Monas melakukan dengan cara selalu introspeksi dan berbenah diri. Hal-hal yang dinilai atau dianggap remeh oleh banyak orang, justru selalu dilihat sebagai hal yang besar. Hal tersebut dilakukan semata untuk mengantisipasi kemungkinan yang terjadi. Memastikan lampu-lampu tetap terang benderang di puncak Monas misalnya. Atau lampu-lampu ruang diorama. Monas menyadari bahwa masyarakat mengenal Monas sebagai ikon ibukota, namun Monas menyayangkan hal tersebut, karena pada dasarnya Monas adalah ikon negara. Selayaknya dan sepantasnyalah masyarakat juga memiliki anggapan yang sama, sehingga bukan hanya masyarakat Jakarta saja yang merasa memiliki Monas tetapi juga seluruh rakyat Indonesia. Monas menyadari tidak mudah mengubah persepsi atas reputasi ini. Tetapi segala hal yang kurang tepat memang harus diluruskan, sejak awal didirikan, Monas merupakan tugu peringatan perjuangan bangsa Indonesia dalam merebut kemerdekaan, sehingga Monas memang dijadikan ikon negara bukan ibukota. Monas tidak merasa perlu menjadikan siapapun menjadikan sosok terkenal sebagai pemberi pengaruh pada masyarakat atas reputasi Monas. Segala sesuaitu berasal dari dalam, apalagi jika ini berkaitan dengan persepsi tentang reputasi sebuah Institusi. Idealnya, memamg pembenahan dan pembentukan, serta penguatan dari dalam dikokohkan, baru kemudian orang bisa melihatnya dari luar, karena itu tercermin dari sikap, perilaku, dan tindakan.

\section{Sudut Pandang Strategi}

Dari sisi strategi, reputasi didefinisikan sebagai sebuah hal yang sulit untuk ditiru atau diduplikasi, karena reputasi justru berasal dari keunikan-keunikan internal yang dimiliki sebuah institusi (Dutton dan Dukerich; Freeman; dalam Balmer dan Greyser, 2003: 226). Di sisi lain, harus diingat dan diindahkan, bahwa institusi harus terus memperhatikan batasan-batasan atau pergerakan reputasinya mengacu pada mobilitas yang juga dimiliki dan dilakukan oleh pesaing atau pihak lain. Secakap apapun reputasi kita, tetap saja akan ada pihak yang dapat mengimitasi reputasi tersebut. Meski mengimitasi atau meniru sebuah reputasi bukanlah perkara mudah, tetapi tetap saja kemungkinan semacam itu selalu ada dan terbuka lebar.

Monas adalah ikon negara, usia Monas tahun ini 50 tahun. Cukup dewasa bagi sebuah institusi dan ikon. Monas menjaga reputasinya yang unik dengan cara memperhatikan seluruh fasilitas yang ada untuk memfasilitasi para pengunjung. Apakah fasilitas tersbut bekerja dengan baik. Peremajaaan terhadap fasilitas tentu saja terus dilakukan, tetapi ada beberapa hal yang tidak dapat diubah. Lift contohnya. Untuk memfasilitasi 2000 pengunjung rata-rata setiap harinya, lift hanya ada satu buah, dan satu buah lift tersebut hanya mampu menampung 11 orang pengunjung untuk naik atau turun. Namun kekhasan Monas justru terletak pada kemampuannya mengelola keterbatasan menjadi bermacam kelebihan.

\section{Sudut Pandang Pemasaran}

Sudut pandang pemasaran. Dalam pemasaran, reputasi dilihat sebagai brand image sebuah institusi. Dalam konteks ini, reputasi adalah hasil dari proses mencerna informasi yang menghasilkan gambaran tersendiri dalam pikiran individu atau seseorang (Lippman; dalam Balmer dan Greyser, 2003: 227). Ekuitas sebuah "brand" tercipta dari integritas antara kesadaran akan sebuah identitas sebuah "brand” dan juga program pemasarannya.

Monas dikenal tidak hanya karena tugu agung nan kokohnya, tetapi juga taman Monasnya. Meski taman Monas dikelola sendiri oleh dinas pertamanan walikota Jakarta Pusat, tetapi tetap saja lokasinya terintegrasi dengan tugu Monas. Masyarakat mengenal Monas dengan daerah tamannya 
yang sangat luas, sehingga banyak orang yang berkegiatan di sana. Mulai dari kegiatan komunitas sampai kegiatan kenegaraan. Sebetulnya ada fungsi lain dari taman monas yang tidak diketahui masyarakat banyak, karena kurangnya promosi dan sosialisasi. Taman Monas dapat dipakai untuk acara perkawinan terbuka atau perkawinan yang mengusung konsep outdoor. Belum pernah ada satupun individu yang mencetuskan pertanyaan semacam ini pada Monas. Pada dasarnya Monas terbuka dan sangat menerima kalau ada masyarakat yang mau menggunakan Monas sebagai lokasi perkawinan mereka, hanya saja tetap ada prosedur dan aturan-aturan yang harus dijalankan dan dipatuhi sebelum perkawinan tersebut dilaksanakan di Monas.

Tiket masuk Monas yang cukup murah memang menjadi daya tarik lain dari ikon besar ini. Monas mengakui bahwa idealnya layanan untuk masyarakat memang murah, namun tidak murahan, dalam arti tetap memperhatikan kualitas kenyamanan, dan kebersihan. Mayoritas pengunjung Monas memang masyarakat dari golongan ekonomi menengah ke bawah. Reputasi Monas sebagai destinasi wisata segala usia dan kalangan hanya berlaku bagi masyarakat golongan tersebut.

Monas tidak memberikan segmentasi tertentu di awal, tetapi memang belakangan Monas mengincar masyarakat kalangan atas untuk lebih mengenal Monas secara lebih dekat. Menurut pengamatan Monas, masyarakat menengah ke atas lebih memilih berekreasi ke luar negeri atau mengunjungi pusat-pusat perbelanjaan. Namun bagi Monas itu bukanlah kendala atau hambatan, justru menjadi pemicu semangat supaya mereka dapat lebih maju dan menjadikan Monas jauh lebih baik setiap harinya, sehingga Reputasi monas sebagai ikon negara, destinasi wisata semua usia dan kalangan dapat terejawantahkan dengan sempurna.

\section{Sudut Pandang Organisasi}

Dalam sudut pandang organisasi, reputasi tumbuh dari pengalaman para pekerja yang ada didalamnya. Reputasi dilatar belakangi oleh budaya organisasi dan didukung kuat oleh identitas korporasi. Budaya institusi mempengaruhi persepsi dan motivasi manager (Barney, Dutton dan Penner; dalam Balmer dan Greyser, 2003: 228), sedangkan identitas institusi akan mempengaruhi bagaimana manager bereaksi dan mengintepretasi kondisi dan situasi yang terjadi di lingkungan sekitarnya (Dutton dan Dukerich; Meyer; dalam Balmer dan Greyser, 2003: 228). Identitas dan budaya merupakan dua hal yang saling berkaitan. Identitas memberi gambaran tentang keutamaan (inti), kelanggengan, dan fitur-fitur khas dari sebuah institusi, yang menghasilkan intepretasi tertentu yang kemudian ditularkan dan dibagikan antar para manager, dimana intepretasi tersebut dipakai untuk menangani atau menghadapi lingkungan atau pihak luar institusi.

Meski sudah menempel secara tertulis aturan-aturan sederhana seperti "Mohon membuang sampah dalam tempat sampah" tetap saja pihak Monas selalu memberi peringatan secara lisan, terbuka, halus namun tegas ketika menemukan para pelanggar aturan di lokasi atau di lapangan. Pengalaman mengajarkan pada para pekerja di Monas bahwa yang terpenting adalah memiliki hati yang lapang dan panjang sabar, karena setiap hari akan selalu ada individu yang membuat pelanggaran secara bergantian, untuk beragam aturan.

\section{Sudut Pandang Sosiologi}

Dalam sudut pandang sosiologi, reputasi dinilai sebagai indikator dari sebuah legitimasi (Granovetter; White; dalam Balmer dan Greyser, 2003: 229). Reputasi merupakan penilaian yang relatif terhadap harapan dan norma dalam bidang kelembagaan. Banyak pihak yang terlibat dan saling terkait dalam proses membangun sebuah reputasi.

Monas tidak terintegrasi dengan taman Monas, meski lokasinya terintegrasi, dan sama-sama berada di bawah naungan Gubernur DKI Jakarta tetapi dikelola oleh pihak yang berbeda. Tugu Monas dikepalai oleh seorang kepala UPT, dan taman Monas dikelola oleh Walikota Jakarta Pusat. 
Pengelolaan yang berbeda terkadang memang membawa kebingungan , bukan hanya pada pihak internal melainkan juga pihak eksternal. Hal itu disebabkan oleh koordinasi yang kadang lalai untuk diseriusi. Dari sudut pandang sosoliogi ini, reputasi dibentuk oleh banyak pihak, dan semakin kuat bila kerjasama semakin rapat. Pengelolaan yang terbagi ini menjadi alat dan wadah untuk menguji kemampuan mereka berkoordinasi dan berkomunikasi dengan pihak lain secara internal. Koordinasi yang baik di area internal akan banyak membantu ketika Monas harus nerhadapan dengan pihak eksternal dengan berbagai sebab serta alasan.

\section{Sudut Pandang Akunting}

Dalam sudut pandang akunting, reputasi dilihat sebagai aset yang tidak terlihat namun dapat diukur (Barney; Rindova; Fombrun; dalam Balmer dan Greyser, 2003: 230). Pengukuran berdasarkan finansial dianggap lebih baik dalam menilai sebuah reputasi. Dalam arti apakah secara finansial Monas menunjukkan peningkatan atau justru penurunan, dilihat dari jumlah pembelian tiket dan akumulasi jumlah pengunjung per periode. Meski dari sudut pandang akunting sebuah reputasi dilihat dari sisi finansial, namun Monas tidak mengukur kinerjanya dengan hal yang sama atau finansial juga. Monas memandang apakah segala seuatunya berjalan atau berlaku sesuai dengan prosedur kerja, aturanaturan tertulis yang ada, atau tidak; jika tidak maka kinerja individu atau departemen atau divisi tersebut dianggap kurang memuaskan.

\section{SIMPULAN}

Monas merupakan representasi ibu kota negara yg sudah berumur 484 tahun, dan tugu itu sendiri sudah berumur 50 tahun. Jadi sudah saatnya monas menunjukkan kedewasaan serta tingkat kematangannya sebagai sebuah institusi yang menjadi ikon sebuah negara. Kompleks Monas terdiri dari dua bagian, yaitu tugu dan taman. Tugu berada di bawah pengelolaan kepala UPT, sedangkan taman di sekelilingnya ada di bawah pengelolaan dinas pertamanan Wilayah Jakarta Pusat. Walaupun dikelola oleh dua manajemen yang berbeda, namun tetap secara keseluruhan komplek Monas berada di bawah kepempinan Gubernur DKI Jakarta. Reputasi monas sebagai sebuah ikon negara dikelola secara sederhana. Monas dapat memajukan diri dengan cara banyak melalukan sosialisasi kepada masyarakat tentang keberadaanya sendiri. Pihak Monas memang tidak berkenan mengeluarkan dana untuk membiayai seorang spoke person/tokoh yang berpengaruh untuk mengajak orang dari kalangan menengah atas untuk pergi berwisata ke Monas dan menggunakan fasilitas MONAS. Saran yang dapat diajukan untuk hal ini adalah mengajak artis/selebritis untuk beracara di Monas dengan sistem barter. Dalam arti acara tersebut secara otomatis dapat mendatangkan media massa untuk meliput apa saja yang ada di Monas yang dipersembahkan khusus untuk masyarakat.

Unique Selling Point Monas adalah Mahkota tugu yang dilapisi emas murni, dan pelataran atas yang difasilitasi oleh teropong untuk melihat seantero Jakarta. Untuk memperkuat fasilitas ini, dapat dibuat kerjasama dengan pihak swasta untuk mengelola bagian-bagian tertentu dari Monas misalnya bagian pelataran bawah dapat dijadikan sebuah tempat kongkow soiree setelah waktu buka museum berakhir. Taman Monas yang indah dan berbagai fasilitas ditaman tersebut dapat diberdayakan dgn cara menyewakannya secara komersil untuk acara-acara pribadi. Misalnya Barbeque, Pernikahan, atau Peringatan. Diruang Diorama banyak orang makan, minum dan menggelar tikar. Ada baiknya larangan membawa makanan atau minumam dari luar ditegaskan, namun menggantinya dengan cara memfasilitasi pengunjung dengan mendirikan counter makanan dan minuman dengan variasi kualitas dan harga. Karyawan Monas kurang memiliki motivasi dan harus diperintah untuk melakukan sesuatu. Hal ini dapat diminimalisir dengan cara memacu dan memicu mereka untuk mendapatkan insentif atas kerja profesional mereka dalam kaitannya dengan kerjasama pihak swasta. 
Kelemahan institusi Monas adalah kurangnya koordinasi. Monas dan Taman Monas dikelola oleh dua institusi berbeda meski keduanya sama-sama ada dibawah Pemda DKI Jakarta. Lebih baik dibuat suatu SOP yang terintegrasi, dan bekerjasama dengan pihak swasta, dan meminimalisir kekisruhan yang disebabkan oleh kurangnya koordinasi, sehingga pihak swasta tidak enggan menanamkan modalnya. Monas tidak mengukur kinerjanya secara finansial. Mereka melihat apakah segala sesuatunya dapat berjalan sesuai prosedur atau tidak. Saran: Seharusnya ada target pemasukan bagi semua karyawan. Ada standar KPI (Key Performance Indicator) untuk semua karyawan yang berhubungan dengan pemberian insentif. Mempertahankan atau mengelola sebuah reputasi bukanlah perkara mudah. Namun kesederhanaan Monas menangani masalah reputasi juga kurang dapat menjawab tantangan jaman. Ada baiknya strategi-strategi yang mengandung kebaruan ditelaah lebih lanjut oleh Monas, dan kemudian berani menerapkannya, demi kelanggengan agungnya Monas, sebagai ikon Negara.

\section{DAFTAR PUSTAKA}

Balmer, J.M.T \& Stephen A. Greyser. (2003). Revealing The Corporation (Perspective on Identity, Image, Reputation, Corporate Branding, and Corporate Level-Marketing). New York: Routledge.

Denzin, N. K. \& Yvonna S. Lincoln. (2005). Handbook Of Qualitative Research, Third Edition. California: Sage.

Griffin, E. M. (2006). A First Look At Communication Theories, Sixth Edition. New York: McGrawHill.

Littlejohn, S.W. (2002). Theories Of Human Communication, Seventh Edition. Wadsworth. California: Belmont.

Miller, K.. (2005). Communication Theories: Perspectives, Processes, and Context, Second Edition. New York: McGraw-Hill.

Moleong, L..(2007). Metodologi Penelitian Kualitatif. Bandung: Rosda.

Neuman, W. L. (2003). Sosial Research Methods, Qualitative and Quantitative Approach, Fifth Edition. USA: Pearson Education.

Samovar, L.A., Richard E. P., \& Edwin R McDaniel. (2007). Communication Between Cultures, Sixth edition. Belmont: Thomson Wadsworth.

Santana, Septiawan. (2007). Menulis Ilmiah: Metode Penelitian Kualitatif. Jakarta: Yayasan Obor Indonesia.

West, R., \& Linn H. Turner. (2004). Introducing Communication Theories, Analysis and Application, Second Edition. New York: McGraw - Hill.

http://www.mediaindonesia.com/read/2011/06/29/238032/38/5/Jumlah-Pengunjung-MonasMeningkat-Saat-Libur-Sekolah, diunduh pada Senin, 26 September 2011, pukul 13.49 
http://www.republika.co.id/berita/nasional/umum/11/07/05/lnua4p-prediksi-bkkbn-2011-pendudukindonesia-241-juta-jiwa, diunduh pada Selasa, 27 September 2011, pada pukul 03.57

http://metropolitan.inilah.com/read/detail/1771282/jumlah-penduduk-jakarta-dekati-ambang-batas, diunduh pada Selasa, 27 September 2011, pada pukul 03.59

http://www.tokyotower.co.jp/english/05_info/index.html, diunduh pada Rabu, 28 September 2011, pukul 17.53.

http://www.nps.gov/nacc/forkids/index.htm, diunduh Jumat, 30 September, pukul 01.40

http://www.asahi.com/english/TKY201107090265.html, diunduh pada Jumat, 30 September 2011, pukul 01.37 